\title{
Thomas Aquinas and Albertus Magnus on the Problem of Evil: Insights from their Commentaries on the Book of Job
}

\author{
Franklin T. Harkins (Boston College)
}

\begin{abstract}
This article broadly considers the commentaries on Job of Thomas Aquinas and Albert the Great as offering a helpful theological alternative to some modern philosophical approaches to the 'problem of evil'. We seek to show that whereas some modern philosophers understand evil as a problem for the very existence of God, whether and how God can coexist with evil was never a question that evil seriously raised in the minds of Aquinas and Albert. In fact, although the suffering of the just in particular led our medieval Dominicans to wonder about divine providence and our ability to know God in this life, they understood the reality of evil as compelling evidence for the existence of God.
\end{abstract}

\section{Keywords}

Commentary on Job $\bullet$ problem of evil $\bullet$ divine providence
EJSTA 39 (2021)

DOI:

10.2478/ejsta-2021-0002

Article history:

Received: 18.8.2021

Accepted: 20.9.2021

Available online:

11.11.2021

The biblical account of Job is a story of profound theological, philosophical, and existential significance that has captivated hearers and readers for centuries. The scriptural book, whose final form scholars generally date to sometime between the seventh and second century BCE, seems intentional in its aim to present universal human themes by way of a cosmic narrative that transcends any particular historical setting. ${ }^{1}$ Across the centuries, readers of all stripes have variously identified these themes, construed and contemplated them in different ways, and, in so doing, have produced a dizzying array of interpretations of Job and his suffering. ${ }^{2}$ All of these readings, however, share a common starting-point, namely the stark realization that there is evil and suffering in the world. Nevertheless, this undeniable truth of the reality of evil has generated a wide range of philosophical and theological responses over the past two millennia.

Significantly, some of these responses to evil are inconsistent with, even diametrically opposed to, others. Some modern philosophers of religion, for instance,

\footnotetext{
${ }^{1}$ See, e.g., T. Longman III, Job (Grand Rapids: Baker Academic, 2012), 24-27; N.C. Habel, The Book of Job: A Commentary (Philadelphia: Westminster Press, 1985), 39-42.

2 See, e.g., F.T. Harkins, Aaron Canty (eds.), A Companion to Job in the Middle Ages (Leiden: Brill, 2016).
} 
assume that the reality of evil and suffering is either logically inconsistent with or at least counts as evidence against the existence of an omniscient, omnipotent, omnibenevolent God: that is, they assume that because evil exists, God - at least the God traditionally conceived by theism - must not exist. Over 750 years ago, Thomas Aquinas was aware of a certain philosopher who, living at least seven centuries before Aquinas' own birth, wondered about this very question that so exercises modern minds: If God exists, whence comes evil? On the face of it, evil seems to be inconsistent with divine existence. Aquinas, however, turns the ancient philosopher's question on its head, maintaining that he should have argued instead, "If evil exists, God exists."3 This article aims to investigate precisely this interpretive problematic: how could Aquinas and Albert the Great have thought so differently about the reality of evil and its implications for God's existence and nature than many modern-day thinkers? How, if at all, did Aquinas and Albert engage what modern philosophers of religion call 'the problem of evil'? Was the problem of evil a real problem for them? Why or why not? And what insights from their Job commentaries in particular informed their distinctive approach to the question of evil and divine existence?

Our treatment will unfold in two major parts. In Part 1, we will provide an overview of the standard modern approach to Job, suffering, and evil, namely the socalled 'problem of evil'. Here we will consider the major theoretical versions of this problem, and we will unearth several of the fundamental assumptions concerning God, the divine will, and the nature of evil that underlie William Rowe's so-called "argument for atheism". ${ }^{4}$ In Part 2, we will encounter in Aquinas and Albert a very different, and expressly theological, approach to Job and his suffering. We begin by contextualizing the Job commentaries of our medieval Dominicans, both of whom understand the book of Job as recounting a debate or disputation on divine providence. We will then move to a treatment of Aquinas on divine unknowability and the whirlwind out of which God finally appears to Job in order to determine the question under discussion. From there we will transition to a consideration of evil, divine existence, and providence according to Aquinas and Albert. We seek to show that for Aquinas and Albert evil never seriously suggests the nonexistence of God; in fact, the opposite is true. As careful theological readers of Job, they assume that if evil exists, God must exist.

\footnotetext{
${ }^{3}$ ScG III, c. 71.

${ }^{4}$ See W.L. Rowe, 'The Problem of Evil and Some Varieties of Atheism', in: American Philosophical Quarterly 16.4 (1979): 335-341, at 336.
} 


\section{The Standard Modern Approach: The Problem of Evil}

Modern readers of Job tend to identify the central themes of the book as the reality of 'innocent suffering' and the so-called 'problem of evil'. ${ }^{5}$ In fact, the biblical book is often treated as if it were essentially a philosophical treatise on the problem of evil. ${ }^{6}$ Eleonore Stump explains the interpretive lens through which Job is commonly read thus: "Since the book itself says that Job was innocent and since the book is equally clear about the fact that Job's suffering is (indirectly) caused by God, who grants Satan permission to afflict him, it seems to contemporary readers that the story of Job's suffering is hard to reconcile with the claim that there is an omnipotent, omniscient, perfectly good God."7 Furthermore, David Clines has observed that many people today understand the essential question raised by the book to be that of the origin and cause of suffering, particularly of their own personal suffering. These are significant existential and philosophical questions, questions to which the book of Job seems to many people today to give no satisfactory answer. ${ }^{8}$ Indeed, one modern theologian has gone so far as to maintain that "[ $t]$ he book of Job makes no coherent claims" concerning human suffering. ${ }^{9}$

From time immemorial, humans have witnessed and suffered a wide range of evils of varying degrees, which suffering has presented them with various philosophical, theological, and existential problems. What is perhaps most interesting is just how differently many modern people tend to think about the central problems that evil raises-and for whom or what these problem are problems-than did medieval Christian theologians like Aquinas and Albert. We will see that for Aquinas and Albert, just as for many people today, evil and suffering raised questions about the moral order governing the world. Likewise, evil confronted our medieval Dominicans with the problem of the goodness and kindness of God toward humans, a problem with which moderns continue to grapple in the face of suffering. But, as we hope to show, the central problem that stands at the heart of the reality of evil for many modern thinkers, namely the question whether God exists, was not really a problem at all for Aquinas and Albert. In other words, evil was certainly a problem for our Dominican theologians, but 'the problem of evil' was not their problem. More on this in Part 2.

\footnotetext{
${ }^{5}$ See, e.g., D.J.A. Clines, Job 1-20, Word Biblical Commentary: Volume 17 (Dallas: Word Books, 1989), xxxviiixxxix; J.E. Thiel, God, Evil, and Innocent Suffering: A Theological Reflection (New York: Crossroad, 2002), 20-27. ${ }^{6}$ E. Stump, Wandering in Darkness: Narrative and the Problem of Suffering (Oxford: Oxford University Press, 2010), 183-184.

${ }^{7}$ E. Stump, Aquinas (London: Routledge, 2003), 460.

${ }^{8}$ Clines, Job 1-20, xxxviii.

${ }^{9}$ T.W. Tilley, 'God and the Silencing of Job', in: Modern Theology 5.3 (1989): 257-270, at 268; cf. Stump, who notes that modern readers often understand the debate among Job and his friends as "an unsatisfactory philosophical discussion because it is taken to break off without a decisive conclusion regarding the problem of suffering" (Wandering in Darkness, 183-184).
} 
To many modern minds-those of professional philosophers of religion, theologians, and ordinary people - the problem of evil is fundamentally a problem for God, indeed a problem for theism itself. That is, evil in the world poses a problem for the very existence of a supreme deity as traditionally understood. Although various conceived, the modern 'problem of evil' is framed explicitly in terms of what Daniel Speak has called "common theism," that is, those commitments shared by the world's principal theistic religions. And the problem generally runs thus:

1. God exists;

2. God is omnipotent;

3. God is omniscient;

4. God is omnibenevolent; and yet

5. Evil exists. ${ }^{10}$

For many today, philosophical tension arises from the attempt to hold these five propositions together. The fifth one in particular presents a problem for common theism, according to problem-of-evil philosophers. If (1) through (4) are true, we should expect (5) not to be true; conversely, if (5) is true, then (1) through (4) seem to be called into question. Chad Meister and Paul Moser explain: “As omnibenevolent, God would not want evil to exist. As omnipotent, God would have the power to make the world exist without evil. As omniscient, God would have the knowledge to accomplish the task. Since there is evil-widespread, horrific evil-there is some reason to believe that such a God does not exist."11

The two basic theoretical versions of 'the problem of evil' understand this reason to believe in divine nonexistence, or to deny divine existence, as more and less strong, respectively. The first version, called 'the logical problem of evil', maintains that the claim that the God of traditional theism exists is logically inconsistent with the reality of evil in the world: because we know (5) to be true, we likewise know that (1) cannot be true - and, by extension, neither can (2), (3), or (4) be true. According to 'the logical problem of evil', which J. L. Mackie first introduced in his 1955 article "Evil and Omnipotence", faith in God not only lacks rational support; it is, in Mackie's words, "positively irrational" in the face of evil and suffering. ${ }^{12}$ Given the reality of evil, the theologian maintains belief in divine existence, according to Mackie, only by means of an "extreme rejection of reason". ${ }^{13}$ Whereas 'the logical problem of evil' appears - to some thinkers, at least-to demonstrate the nonexistence of God, the second version of the modern 'problem of evil' is somewhat weaker. 'The evidential problem of evil' maintains that, although theism may not be logically inconsistent

\footnotetext{
${ }^{10}$ D. Speak, The Problem of Evil (Cambridge: Polity Press, 2015), 4-6.

${ }^{11}$ C. Meister, P.K. Moser (eds.), The Cambridge Companion to the Problem of Evil (New York: Cambridge University Press, 2017), 3.

${ }^{12}$ J. L. Mackie, 'Evil and Omnipotence', in: Mind 64 (1955): 200-212, at 200.

${ }^{13}$ Mackie, 'Evil and Omnipotence', 200.
} 
with evil, the reality of evil does provide evidence against the existence of the God of traditional theism. ${ }^{14}$

To set the stage further for our medieval Dominican readings of Job, let us consider 'the evidential problem of evil' in somewhat greater detail. It was the analytic philosopher William L. Rowe, more than anyone else, who determined the agenda for the contemporary discussion of this problem in his 1979 article, "The Problem of Evil and Some Varieties of Atheism". ${ }^{15}$ Rowe's principal aim here was to determine whether there is "an argument for atheism based on the existence of evil that may rationally justify someone in being an atheist". ${ }^{16}$ In other words, can or does evil authorize atheism? This, of course, is a common question that the book of Job raises in the minds of many readers today. But medieval Christian thinkers like Aquinas and Albert would have been baffled by the notion that Job's suffering - or anyone else's might somehow legitimate atheism. As we will see, Job's suffering raised very different questions for Aquinas and Albert. And this fundamental exegetical dissimilarity is traceable, we suggest, to radically divergent assumptions about God, the divine will and its knowability by humans, and the nature of evil. In an effort to unearth these basic assumptions, we quote Rowe verbatim here. His evidential argument runs thus:

1. There exist instances of intense suffering which an omnipotent, omniscient being could have prevented without thereby losing some greater good or permitting some evil equally bad or worse.

2. An omniscient, wholly good being would prevent the occurrence of any intense suffering it could, unless it could not do so without thereby losing some greater good or permitting some evil equally bad or worse.

3. There does not exist an omnipotent, omniscient, wholly good being. ${ }^{17}$

Although much could be said about Rowe's argument, let us make three points with an eye toward the perspective of Aquinas and Albert. First, Rowe's conclusion (point 3), which appears to follow validly from the premises (points 1 and 2), is that God does not exist. What we have here, then, is an attempt at an explicit proof or demonstration of divine nonexistence in the face of evil, what Rowe himself calls an "argument for atheism". ${ }^{18}$ Rowe assumes rather straightforwardly that if evil exists, then God must not exist. God and evil simply cannot coexist; they are mutually exclusive. Such an "argument for atheism" is generally thought to stand in contrast to other contemporary approaches to 'the problem of evil' such as, for example: (1) the defense against evil, which attempts to show that God could have morally sufficient

\footnotetext{
${ }^{14}$ Meister, Moser (eds.), Cambridge Companion, 4.

${ }^{15}$ W.L. Rowe, 'The Problem of Evil and Some Varieties of Atheism', in: American Philosophical Quarterly 16.4 (1979): 335-341; see also the summary of Rowe in Speak, Problem of Evil, 49-52.

${ }^{16}$ Rowe, 'The Problem', 335.

17 Rowe, 'The Problem', 336.

18 Rowe, 'The Problem', 336.
} 
reasons for allowing various evils; and (2) theodicy, which aims to identify the morally sufficient reasons or purposes God seems to have for allowing evil. ${ }^{19}$ It must be noted, however, that some significant theodicies have, like Rowe's argument, also pointed in the direction of divine nonexistence. Theodicy, a specifically modern philosophical discipline that originated with Leibniz, is hardly a single, monolithic enterprise. ${ }^{20}$ Whereas many theodicies begin with the assumption that God exists and from there proceed to explore whether and how we might make moral sense of God's permitting evil, others understand the question of God's existence as constituting the heart of the theodicy problem. ${ }^{21}$ Indeed, one radical modern answer to the question of why God created a world wherein evil is found is offered by the philosophy of autonomy beginning with Immanuel Kant and Johann Gottlieb Fichte in the $18^{\text {th }}$ century. According to autonomization, of which the myth of the death of God became a part in the $19^{\text {th }}$ century, it is not God who created such a world, but rather human beings. Odo Marquard has described autonomization as an "uncommonly influential thesis" that "was made necessary by theodicy, as a way of unburdening God by relieving him of his duties as the Creator god, whose successor (with the job of unburdening God) is man the autonomous creator." 22 For Friedrich Nietzsche, God is justified in the face of evil only by His own nonexistence. ${ }^{23}$ The "old God" in whom the whole world once believed is now dead, Nietzsche claimed, and "it is of his pity for human beings that God has died." 24 Unlike Nietzsche and Rowe, Aquinas and Albert do not understand evil as a threat to divine existence. To the contrary, our medieval Dominicans understand the eternally existing God as having revealed Himself to Job and to humankind generally in a particularly significant way in the midst of the evils that Job experienced.

Our second point concerning Rowe's argument is closely related to the first. In his premises, Rowe presumes that we humans can and do know what an omnipotent, omniscient, and omnibenevolent God wills and what such a God can, would, and should do in terms of allowing or preventing evil in the world. Furthermore, Rowe's assumptions about God run contrary to the willing and acting of the God who reveals Himself in and through the book of Job. In fact, Rowe's argument is an attempt at the sort of human, philosophical calculus concerning the divine will and operation that we work out in vain according to the book of Job. Indeed, following God's self-

\footnotetext{
${ }^{19}$ Meister, Moser, Cambridge Companion, 4.

${ }^{20}$ See O. Marquard, In Defense of the Accidental: Philosophical Studies, trans. Robert M. Wallace (New York: Oxford University Press, 1991), 11-13, who says: "Where there is theodicy, there is modernity, and where there is modernity, there is theodicy" (11).

${ }^{21}$ K. Surin, Theology and the Problem of Evil (Oxford: Blackwell, 1986), 1.

${ }^{22}$ Marquard, In Defense of the Accidental, 15.

${ }^{23}$ Marquard, In Defense of the Accidental, 16-17.

${ }^{24}$ F. Nietzsche, Thus Spoke Zarathustra: A Book for Everyone and Nobody, trans. Graham Parkes (Oxford: Oxford University Press, 2005), 77; see also 226-227.
} 
disclosure from the whirlwind, Job himself admits that he had spoken foolishly and beyond his limited human understanding. ${ }^{25}$

Third, it must be observed that Rowe understands God - and, by extension, theism and atheism - rather differently than do Aquinas and Albert. Rowe's God appears to be a highly anthropomorphized deity of whom one can speak with kataphatic ease, the generic God of common theism who is a unipersonal being among or alongside beings in the universe. Rowe's God fits well Kenneth Surin's description of the divinity of modern theism, who is "' a' being ..., a rare and fascinating 'entity', possessing a number of clearly specifiable characteristics." ${ }^{26}$ Indeed, Rowe describes God as "an omniscient, wholly good being" who seeks to obtain the greatest good possible in the world at all times. ${ }^{27}$ Relatedly, he defines a theist thus: "By a 'theist' in the narrow sense I mean someone who believes in the existence of an omnipotent, omniscient, eternal, supremely good being who created the world. By a 'theist' in the broad sense I mean someone who believes in the existence of some sort of divine being." 28 Conversely, Rowe explains, "To be an atheist in the broad sense is to deny the existence of any sort of divine being." ${ }^{29}$ Here God is imagined to be what René Descartes understood a human to be, namely, in the words of Brian Davies, "a person without a body who invisibly thinks and wills and lives a life as our contemporary". ${ }^{30}$ Although Rowe envisions God in such kataphatic, 'personal' Cartesian terms and defines an atheist as anyone who denies the existence of such a being, our medieval Dominicans certainly thought very differently about both God and atheism. Herbert McCabe explains:

Very frequently the man who sees himself as an atheist is not denying the existence of some answer to the mystery of how come there is anything instead of nothing; he is denying what he thinks or has been told is a religious answer to this question. He thinks or has been told that religious people, and especially Christians, claim to have discovered what the answer is, that there is some grand architect of the universe who designed it, just like Basil Spence only bigger and less visible, that there is a Top Person in the universe who issues arbitrary decrees for the rest of the persons and enforces them because he is the most powerful being around. Now if denying this claim makes you an atheist, then I and Thomas Aquinas and a whole Christian tradition are atheistic too. ${ }^{31}$

\footnotetext{
${ }^{25} \mathrm{Job} 42,3$.

${ }^{26}$ Surin, Theology and the Problem of Evil, 5.

27 Rowe, 'The Problem', 336.

${ }^{28}$ Rowe, 'The Problem', 335, emphases mine.

${ }^{29}$ Rowe, 'The Problem', 335, emphasis mine.

${ }^{30}$ Brian Davies, Aquinas (London: Continuum, 2002), 185.

${ }^{31}$ H. McCabe, 'A Modern Cosmological Argument', in: B. Davies (ed.), Philosophy of Religion: A Guide and Anthology (Oxford: Oxford University Press, 2000), 196-201, at 200. Cf. A. Plantinga, Does God Have a Nature? (Milwaukee: Marquette University Press, 1980), 1, who approvingly claims that "Christians think of God as a being of incomparable greatness . . . the first being of the universe, one than whom it is not so much as possible that there be a greater."
} 
Assuming that Thomas Aquinas and traditional Christianity are not atheistic, we might conclude that philosophers such as William Rowe have a muddled notion of God. ${ }^{32}$ Aquinas doubtless would have understood their concept of God as idolatrous, failing fundamentally to distinguish the Creator from creation. ${ }^{33}$ Similarly, Albert maintains that, although the created human intellect can touch upon God by way of simple intuition, it cannot comprehend God with a certain and definite knowledge. ${ }^{34}$ According to the apophatic approach of Aquinas and Albert, we humans do not and cannot have a positive, quidditative concept of God at all. Though we can naturally know that God exists and what God is not, we simply cannot know what God is. ${ }^{35}$ Whereas Rowe generally defines God as "some sort of divine being," Aquinas and Albert deny that God can be defined according to any of the modes of composition whereby creatures are commonly understood. Divine simplicity means, among other things, that God does not belong to any genus or species whatsoever; in other words, God is precisely not "some sort of divine being". God is not, in fact, any kind of being at all. ${ }^{36}$ We will soon see how this thoroughgoing apophaticism shapes how our medieval Dominicans read Job and understand divine providence and evil in the world.

Finally, a third version of the modern problem of evil, related to the evidential problem, is the argument from 'divine hiddenness', according to which what is termed 'reasonable unbelief' or 'inculpable nonbelief' serves as evidence against divine existence. Daniel Speak explains: "God is hidden in the sense that there are some people who, despite having both the rational capacities and volitional dispositions to believe that God exists, find themselves without the experiences or

32 See Surin, Theology and the Problem of Evil, 4, who describes philosophical theism as both "profoundly unchristian" and "conceptually confused".

${ }^{33}$ See F.T. Harkins, Thomas Aquinas: The Basics (London: Routledge, 2021), 41-42.

${ }^{34}$ Albert, Summa theologiae (hereafter: STh) lib. I, tr. 3, q. 13, cap. 1, resp. and ad 1-9 (Opera Omnia t. 34 p. 1: Summa theologiae sive De mirabili scientia Dei, Libri I pars 1, Quaestiones 1-50A, ed. Dionysius Siedler with Wilhelm Kübel and Heinrich George Vogels [Aschendorff: Monasterii Westfalorum, 1978], p. 41 11. 3-7, 2124. Whenever possible and unless otherwise noted, Albert's STh will be cited according to this volume of the Cologne edition.).

${ }^{35}$ See Aquinas, STh I, q. 2, a. 2, co. and ad 1; q. 2, a. 3, co.; and q. 3, prol; and Albert, STh I, tr. 3, q. 14, cap. 1, sol., who explains that from natural things alone it can be known positively that God is, but what God is can be known only infinitely, that is, not according to any finite genus or species or difference or number (t. 34/1, p. 51 11. 17-22). Significantly, Albert takes this to be the basic meaning of Elihu's words in Job 36,25: Omnes homines vident eum, unusquisque intuetur procul (Super Iob, on 36, 25, in: B. Alberti Magni O. Praed. Ratisbonensis Episcopi Commentarii in Iob: Additamentum ad Opera Omnia B. Alberti, ed. Melchior Weiss [Freiburg im Breisgau: Herder, 1904], col. 425 11. 19-28).

${ }^{36}$ See Aquinas, STh I, q. 3, a. 5, co.; and Albert, STh I, tr. 3, q. 14, cap. 1, sol.; STh I, tr. 4, q. 20, cap. 1, sol.; STh I, tr. 4, q. 20, cap. 2, sol. (t. 34/1, p. 51 11. 1-71; p. 98 11. 84-87; p. 101 11. 46-60). It is noteworthy that the traditional doctrine of divine simplicity, particularly as propounded by Aquinas, has been roundly critiqued by some modern philosophers and theologians. Alvin Plantinga, for instance, has claimed that the Thomistic doctrine is "entirely unacceptable" and "an utter mistake" by virtue of the fact that it makes God nothing more than "a state of affairs, ... a mere abstract object and not a person at all", which Plantinga takes to be "clearly inconsistent with the claims of Christian theism at the most basic level" (Does God Have a Nature?, 47, 52-53). 
evidences they reasonably require in order to manifest this belief." ${ }^{37}$ Such hiddenness provides evidence against the existence of God, the argument runs, because if a perfectly good - and thus perfectly loving-God existed, such a God would not be hidden from anyone whatsoever. This is so because a perfectly loving God is, according to J. L. Schellenberg, "a God who is always open to a personal relationship (i.e., an explicit, conscious, interactive relationship) with any finite person", and so no finite person would ever be "nonresistently in a state of nonbelief in relation to the proposition that God exists". ${ }^{38}$ But some "finite persons" - Schellenberg's designation for humans - are in such a state of nonbelief vis-à-vis a perfectly loving God, and so it may reasonably be concluded that such a God does not exist. ${ }^{39}$ Schellenberg's God is a highly anthropomorphized, "unsurpassably great personal being" who is perfectly loving and therefore "seeks to be personally related to all human beings". ${ }^{40}$

For Aquinas and Albert, by contrast, God cannot be identified as either a 'being' or a 'person' in the way these terms are predicated of creatures; nor is God really related to any creature whatsoever. ${ }^{41}$ This is so because, as Aquinas teaches, "God is outside the order of all of creation." ${ }^{42}$ Likewise, Albert explains: "For inasmuch as the divine substance is separate from everything, it is exceedingly eminent and infinitely unnameable." 43 But God's separation from the entire created order does not mean that He is absolutely remote and indifferent to creatures. In fact, the opposite is true. It is precisely the excellence of the divine nature - that is, God's being beyond all 'beings' and 'persons' as their first cause-that enables Him to be most profoundly and intimately present to and in all creatures. ${ }^{44}$

\section{Aquinas and Albert on Job}

\section{Contextualization and Orientation: A Disputation concerning Providence}

It is historically noteworthy that Aquinas, the renowned student of Albertus Magnus, actually produced his Job commentary before Master Albert penned his. Furthermore, Albert seems to have taken what he understands as the organizing principle of the

\footnotetext{
${ }^{37}$ Speak, Problem of Evil, 74.

${ }^{38}$ J. L. Schellenberg, 'Evil, Hiddenness, and Atheism', in: Meister and Moser, Cambridge Companion, 108-123, at 111.

${ }^{39}$ Schellenberg, 'Evil, Hiddenness, and Atheism', 111.

${ }^{40}$ Schellenberg, 'Evil, Hiddenness, and Atheism', 112; and J.L. Schellenberg, Divine Hiddenness and Human Reason (Ithaca: Cornell University Press, 1993), 17, 24-25.

${ }^{41}$ See, e.g., Aquinas, STh I, q. 13, a. 5, co.; STh I, q. 13, a. 7, co.; STh I, q. 28, a. 1 ad 3; STh I, q. 29, a. 3, co.; STh I, q. 45, a. 3, ad 1; and Albert, STh I, tr. 3, q. 16, sol.; STh I, tr. 10, q. 44, cap. 1, sol. (t. 34/1, p. 82 11. 29-65; p. 345 11. 4-33).

${ }^{42}$ Aquinas, STh I, q. 28, a. 1 ad 3: “Deus est extra ordinem totius creaturae, nec ex eius natura est eius habitudo ad creaturas." Unless otherwise noted, all translations of Latin texts in this article are my own.

${ }^{43}$ Albert, STh I, tr. 3, q. 16, sol.: "Inquantum enim segregata est substantia divina ab omnibus, excellenter eminens et infinite innominabilis" (t. 34/1, p. 82 11. 46-48).

${ }^{44}$ See Aquinas, STh I, q. 8, a. 1, co.
} 
book of Job from his famous student-namely, that the biblical book recounts an academic disputation among Job and his friends on the topic of divine providence. ${ }^{45}$

Aquinas produced his Expositio super Iob ad litteram while serving as conventual lector at the priory of San Domenico in Orvieto during the period $1261-64 .{ }^{46}$ Of all the sacred books that Aquinas might have selected as the basis for his cursory lectures to his Dominican confreres at Orvieto, he chose Job. Furthermore, whereas the majority of Aquinas' lectures on scriptural books have come down to us in the form of student notes (reportationes), his commentary on Job carries the title expositio, indicating that Thomas himself revised and prepared the work for publication. ${ }^{47}$ This intimates Aquinas' special regard for the book of Job and his comments on it. It is also noteworthy that during the period 1261-65 Aquinas penned several other works, most notably the Summa contra Gentiles, in which he treats theological themes that figure centrally in his Expositio super Iob: divine providence, the person and work of Christ, the human person's natural knowledge of God, the necessity of faith, bodily resurrection, and final judgment. For Aquinas, God has revealed His sacred doctrine concerning these seminal themes in and through the writings of the Old and New Testaments.

In the Prologue to his Expositio, Aquinas indicates the problem in response to which the book of Job was written: it is an unmistakably human problem, not a problem for God. The problem is primarily epistemological and theological, but with significant cultic and moral implications, namely that humans may not naturally or easily apprehend the extent of divine providence vis-à-vis human affairs. ${ }^{48}$ "It turns out," Aquinas explains, "that from the beginning many [humans] have erred on account of imperfect knowledge concerning the truth [of divine providence]." ${ }^{49}$ Some have swept away divine providence altogether, attributing everything to fortune and chance; others have understood that nature-because of its apparent order-is governed by providence, but have doubted whether human affairs - which manifest no certain order - are sustained and guided by divine care. With apparent sympathy for this latter position, Aquinas observes: "For good things do not always happen to good people or bad things to bad people. Neither, on the other hand, do bad things always happen to good people, nor good things to bad people; rather, good and bad

\footnotetext{
${ }^{45}$ R. Meyer, 'A Passionate Dispute Over Divine Providence: Albert the Great's Commentary on the Book of Job', in: Harkins, Canty (eds.), Companion to Job, 201-224, at 201.

${ }^{46}$ See F.T. Harkins, 'Christ and the Eternal Extent of Divine Providence in the Expositio super Iob at litteram of Thomas Aquinas', in: Harkins, Canty (eds.), Companion to Job, 161-200, at 164-168, on which the following summary depends.

${ }^{47}$ See T. Prügl, 'Thomas Aquinas as Interpreter of Scripture', in: Rik Van Nieuwenhove and Joseph Wawrykow (eds.), The Theology of Thomas Aquinas (Notre Dame: University of Notre Dame Press, 2005), 386415 , at 387.

${ }^{48}$ Aquinas, Expositio super Iob ad litteram (hereafter: In Iob), Prol. (Sancti Thomae de Aquino Opera Omnia, ed. Leo XIII P. M., t. 26: Expositio super Iob ad litteram [Rome: Ad Sanctae Sabinae, 1965], 11. 1-48).

${ }^{49}$ In Iob, Prol., 1l. 6-8.
} 
things happen indifferently to good and bad people."50 For Aquinas, this basic epistemological problem - that we humans may not naturally know that God's providence extends to human affairs - has grave cultic and ethical implications: namely, no fear and love of God in connection with the truth will remain among humans, who will be indolent concerning the virtues and greatly inclined toward vice. It is precisely as an antidote to these ills, according to Aquinas, that God has revealed Himself to and through Job. Indeed, Aquinas teaches that those ancients who "sought wisdom by means of the divine spirit for the instruction of others" - presumably the human writers of scriptural texts such as Job - had as their "first and most important task" to remove from human hearts the opinion that human affairs are not governed by God. ${ }^{51}$ For Aquinas, "the whole intention" of the book of Job is "to show by means of probable arguments (per probabiles rationes) that human affairs are directed by divine providence." 52 But, because the suffering of the just appears to undermine the very foundation of providence, this sacred book proposes, as the topic of the question under discussion, "the manifold and severe suffering of a certain man, perfect in every virtue, who is called Job." 53 For Aquinas, then, Job's suffering provides an extreme case study, as it were, by means of which Job, Eliphaz, Bildad, and Zophar debatein the manner of a medieval scholastic disputation - the crucial quaestio of the divine governance of human affairs. In short, Aquinas' Expositio is, as Jean-Pierre Torrell has noted, "a profound meditation on the human condition", particularly on the fact that the suffering of the just may "inspire doubts about the existence of divine justice" ${ }^{54}$ But significantly, on Aquinas' reading, such suffering never inspires doubts about the existence of God. The same is true of Albert as well.

Albert the Great produced his commentary on Job, entitled simply Super Iob, when he was over seventy years old in Cologne, at the Dominican convent of Heilige Kreuz, where he appears to have resided as lector emeritus of the Order from 1269 until his death in 1280. ${ }^{55}$ According to the manuscripts, Super Iob was completed in either 1272 or 1274 . And it appears that Albert's commentary, like Aquinas', grew out of lectures he gave to his Dominican confreres. As mentioned earlier, Albert's basic assumption concerning the fundamental nature of the book of Job-that it is an academic disputation among Job and his friends concerning divine providenceappears to have been taken from Aquinas' Expositio and developed more fully in Super

\footnotetext{
${ }^{50}$ In Iob, Prol., 11. 32-35.

${ }^{51}$ In Iob, Prol., 11. 48-51.

52 In Iob, Prol., 11. 55-57.

${ }^{53}$ Aquinas, In Iob, Prol., 11. 66-71.

${ }^{54}$ J.-P. Torrell, O.P., Saint Thomas Aquinas, Volume 1: The Person and his Work, revised edition, trans. Robert Royal (Washington, D.C.: Catholic University of America Press, 1996), 121.

${ }^{5}$ See F.T. Harkins, 'Introduction' to St. Albert the Great On Job, volume 1, trans. F.T. Harkins (Washington, D.C.: Catholic University of America, 2019) (hereafter: On Job, vol. 1), 15-19, on which the following overview depends.
} 
Iob. Indeed, as Ruth Meyer has noted, Albert is unique in the history of Joban commentators in understanding the entire biblical book as a disputation. ${ }^{56}$

Albert sketches the contours of the disputation at the outset of his comments on chapter 3, where Job first opens his mouth and speaks to the friends who sat with him in silent solidarity for a week following his unimaginable suffering (Job 2,13-3,1). Here Albert describes the book of Job as containing "a complete disputation among five people-namely, Job, Eliphaz, Bildad, Zophar, and Elihu-concerning the allencompassing providence or care by which the Creator rules and governs human affairs" ${ }^{57}$ All of the disputants agree on three fundamental points, Albert proceeds to explain:

1. That God, who is "the Creator and Governor" (creatorem et gubernatorem), possesses perfect knowledge of all human affairs.

2. That there is absolutely no "unfairness or sin" (iniquitas vel peccatum) in God's governing.

3. That God considers human actions more intimately than does the human who performs them, and therefore God sometimes grasps a defect in those actions that escapes the notice of the human himself. ${ }^{58}$

Beyond these basic points of correspondence, the views of the interlocutors variously diverge. Eliphaz endorses a straightforward act-consequence model, maintaining that God governs human affairs according to merits, repaying good people with good things and bad people with bad things, though he acknowledges that human sinfulness and demerit sometimes remain hidden from humans themselves. ${ }^{59}$ Bildad, in contrast, denies that divine providence rules human affairs according to merits; rather, God always governs with an eye toward what is best in relation to the end of human happiness. On Albert's reading of Bildad's line of argument, if God sometimes brings forth bad things for good people, He compensates for this by giving them many good things in the end. ${ }^{60}$ Albert himself seems to have some sympathy for this teleological perspective, which he received from Moses Maimonides. ${ }^{61}$ Job's third friend, Zophar, holds that God governs human affairs according to His divine will alone, the cause of which cannot be known and therefore should not be sought by humans. For Albert, Zophar's rhetorical questions in Job 11,78 epitomize his position: Will you, by chance, comprehend the steps of God, and will you get to know the Almighty perfectly? He is higher than heaven, so what will you do? ${ }^{62}$ Like Zophar, Elihu, who enters the debate only in chapter 32, maintains that no human can

\footnotetext{
${ }^{56}$ Meyer, 'A Passionate Dispute', 201 and n. 6; Harkins, 'Introduction' to On Job, vol. 1, 17.

${ }^{57}$ Albert, Super Iob 3,1 (ed. Weiss, col. 50 11. 39-44; On Job, vol. 1, 93).

${ }^{58}$ Albert, Super Iob 3,1 (ed. Weiss, col. 50 1. 44 - col. 51 1. 8; On Job, vol. 1, 93).

${ }^{59}$ Albert, Super Iob 3,1 (ed. Weiss, col. 52 11. 7-20; On Job, vol. 1, 94-95).

${ }^{60}$ Albert, Super Iob 3,1 (ed. Weiss, col. 52 1l. 21-34; On Job, vol. 1, 95).

${ }^{61}$ Meyer, 'A Passionate Dispute', 219-220.

${ }^{62}$ Albert, Super Iob 3,1 (ed. Weiss, col. 52 11. 35-46; On Job, vol. 1, 95).
} 
completely understand the operations of divine providence. Elihu adds, though, that God sometimes grants to particular humans - through dreams or angelic mediationa degree of insight into His will. ${ }^{63}$ Even if it is assumed that the inner-workings of God's providential will are ordinarily inaccessible to the human mind, all of Job's friends generally assume that divine providence and justice must somehow operate according to human justice. ${ }^{64}$

Job too held to this view at first, as is manifest, according to Albert, when he declares: If I will be judged, I will be found just $(13,18)$; and If only my sins, for which I deserved wrath, and the calamity that I suffer were weighted out on scales! $(6,2) .{ }^{65}$ With such words Job maintains his righteousness, Albert teaches, because "[i]t seemed to Job that God ought to have governed as if the justice of human governance was the exemplar of the order of divine justice" ${ }^{66}$ But both Job and his friends required divine correction on this point. Indeed, Albert declares that "God alone is able to determine this disputation"; and He does so out of the whirlwind (de turbine; 38,1), which phrase Albert takes as a reference to the "clash" or "conflict" (de conflictu) of the disputation itself. ${ }^{67}$ In his magisterial determination of this disputed question, God reveals - contra the initial position of Job and those of his friends - that He rules human life without consideration of human merits. ${ }^{68}$ "But when the Lord finally settles the disputation," Albert explains, "Job realizes that the order of divine justice is utterly different from the order of human justice. For the human person, who is created from mud, is not so dignified that God should be obliged by the order of human justice." ${ }^{69}$ In short, the mysterious operations of divine providence, which infinitely surpass human understanding, are not and cannot be constrained by the expectations of human providence.

\section{Aquinas on the Whirlwind and the Limited Knowability of God}

For Aquinas, the whirlwind out of which God speaks at the end of Job points not, as Albert understands it, to the conflict of the disputation itself. Rather, Aquinas reads the phrase de turbine in Job 38,1 "metaphorically" (metaphorice) as signifying "the

\footnotetext{
${ }^{63}$ Albert, Super Iob 3,1 (ed. Weiss, col. 52 1. 47 - col. 53 1. 14; On Job, vol. 1, 95-96).

${ }^{64}$ See Albert, Super Iob 37,24 and 38,1 (ed. Weiss, col. 440 11. 1-18 and col. 441 11. 9-12); and Harkins, 'Introduction' to On Job, vol. 1, 36-37.

${ }^{65}$ Albert, Super Iob 3,1 (ed. Weiss, col. 51 11. 11-15; On Job, vol. 1, 93).

${ }^{66}$ Albert, Super Iob 3,1 (ed. Weiss, col. 51 11. 22-25; On Job, vol. 1, 93).

${ }^{67}$ Albert, Super Iob 37,24 and 38,1 (ed. Weiss, col. 440 11. 24-25 and col. 442 11. 15-17).

${ }^{68}$ Albert, Super Iob 38,1 (ed. Weiss, col. 440 1. 32 - col. 441 1. 12).

${ }^{69}$ Albert, Super Iob 3,1 (ed. Weiss, col. 51 11.30-36; On Job, vol. 1, 94). See also Super Iob 9,22, where, commenting on Job's words, He [namely God] consumes both the innocent and the wicked, Albert explains that Job himself understood and held this position significantly earlier in the narrative: "Indeed, from this it is clearly shown that the life of man is not governed according to the order of human justice, and this is the position of blessed Job. Indeed, no one, having been weighed in the divine balance, is innocent before God, although someone might be found innocent before men" (ed. Weiss, col. 138 11. 28-35; On Job, vol. 1, 199).
} 
interior inspiration divinely committed to Job himself". ${ }^{70}$ The sacred text speaks metaphorically of God responding to Job out of the whirlwind not only to indicate the disturbance that Job continued to suffer at that time, Aquinas explains, but also "on account of the obscurity of the whirlwind, that is, because in this life we cannot perceive divine inspiration clearly, but with a certain overshadowing of sensible similitudes". ${ }^{71}$ By virtue of its obscurity, the physical whirlwind serves as a metaphor for the inability of humans to receive divine revelation directly and understand it plainly. This human epistemological limitation vis-à-vis divine revelation is precisely what God reveals to and through Job, on Aquinas' reading.

This interpretation of de turbine returns us to the Prologue of the Expositio and recapitulates Aquinas' teaching concerning the purpose of the book of Job, namely to make clear to us humans - who may have little or no natural knowledge of this truththat divine providence does, in fact, extend to human affairs. Aquinas and Albert agree that God Himself had to enter the disputation precisely because this question of where and how God is to be found among human affairs often proves too challenging for us. "But because human wisdom is not sufficient to comprehend the truth of divine providence," Aquinas explains, "it was necessary that the preceding debate be determined by divine authority."72 It is important to note that, although God's selfrevelation in Job 38-41 shows that God governs human affairs, it does not indicate positively how divine providence operates. Even here, God appears out of the whirlwind, after all.

Aquinas, like Albert, takes very seriously the limits on our ability to know God. ${ }^{73}$ Both of our Dominicans understand that when theologians talk about God, they do not actually know what they are talking about. ${ }^{74}$ They take the view that in this life we humans simply do not, and cannot, have any positive idea of what God is, and much less how precisely God governs human affairs. Of Aquinas on this point, Herbert McCabe says: "He was, I suppose, the most agnostic theologian in the western Christian tradition - not agnostic in the sense of doubting whether God exists, but agnostic in the sense of being quite clear and certain that God is a mystery beyond any understanding we can now have."75 For Aquinas and Albert, we can naturally know only what God is not by causal inference from His created effects, that is, only by way of remotion or privative understanding: we can know, for instance, that God is not

\footnotetext{
${ }^{70}$ In Iob 38,1, 11. 25-29.

${ }^{71}$ In Iob 38,1, 11. 29-34.

72 In Iob 38,1, 11. 5-8.

${ }^{73}$ See, e.g., Albert, STh I, tr. 3, q. 13, cap. 1, resp., who teaches that we humans cannot determine "what or what kind God is" (quis vel qualis deus); rather, we can only know God "in a symbolic or mystical way" (symbolico vel mystico modo), that is, infinitely or negatively through knowing creatures (t. 34/1, p. 40 11. 3967). See also Albert, STh I, tr. 3, q. 14, cap. 1, sol. (t. 34/1, p. 51 11. 1-71).

${ }^{74} \mathrm{H}$. McCabe, 'A Very Short Introduction to Aquinas', in: B. Davies and P. Kucharski (eds.), The McCabe Reader (London: Bloomsbury T\&T Clark, 2016), 239-255, at 241.

${ }^{75}$ McCabe, 'A Very Short Introduction', 241.
} 
corporeal, temporal, or finite. ${ }^{76}$ Even when we are able to have what Albert calls a "positive understanding" (positivus intellectus) of God-knowing, for example, that He is an incorporeal substance - we cannot define the divine substance in terms of genus, species, difference, and number because it is "infinitely eminent beyond every substance" (infinite eminens super omnem substantiam). ${ }^{77}$

The traditional doctrine of divine simplicity exemplifies the apophaticism of Aquinas and Albert. Whereas we know created beings by knowing the various ways in which they are composed-according to body and soul, matter and form, essence and existence, for example-God cannot be known in any of these ways because He is wholly incomposite. Rather, God is "entirely simple" (omnino simplex) or "truly simple" (vere simplex), undetermined by any parts or any mode of composition. ${ }^{78}$ Albert teaches that divine simplicity is of an entirely different order from the modes of simplicity of various created things, such as the simplicity of unity, of a point, of quantity, of a homogeneous body, and of the principles of a substance. To the objection of some thinkers who note that Scripture calls God "a rock and a place and sometimes water and things of this sort, which are homogeneous bodies" (e.g., 2 Sam 22,2; Ps 132,5; Jer 2,13), Albert responds: "But this is nonsense, because such things are said of God symbolically", describing Him "by dissimilar likenesses of analogies" (per dissimiles similitudines proportionum) rather than "by the nature of the simple or composite essence in God."79 In short, for both Albert and Aquinas, God is not a being of this or that kind, with this body and that soul, this matter and that form, this essence and that existence. Rather, unlike every created being, God's essence is His existence. ${ }^{80}$ Indeed, what it means to be God is to be existence itself, that is, to be to-be (esse). ${ }^{81}$ So God is not a composite being; rather God is simply to-be. Aquinas and Albert, then, understand the word 'Deus' as a verb more than as a noun: God is pure act (actus purus), subsistent to-be itself (ipsum esse subsistens). ${ }^{82}$ As pure actuality and subsistent to-be, God cannot fail to exist. ${ }^{83}$ This is true, according to Aquinas and Albert, apart from any consideration of creation and evil of any kind, including human suffering.

\footnotetext{
${ }^{76}$ See, e.g., Aquinas, STh I, q. 3, Prol.; q. 3 a. 1 co.; q. 3, a. 7 co.; and Albert, STh I, tr. 3, q. 14, cap. 1, sol. (p. 51 11. 35-43).

77 Albert, STh I, tr, 3 q. 14 cap. 1, sol. (p. 51 1l. 17-34).

${ }^{78}$ Aquinas, STh I, q. 3, a. 7, obj. 1, sed contra, and co.; and Albert, STh I, tr. 4, q. 20, cap. 2, sol. (t. 34/1, p. 101 11. 46-60).

${ }^{79}$ Albert, STh I, tr. 4, q. 20, cap. 2, sol. (t. 34/1, p. 100 11. 64-70).

${ }^{80}$ Aquinas, STh I, q. 2, a. 1 co.; I, q. 3, a. 4, co.

${ }^{81}$ See David B. Burrell, C.S.C., Aquinas, God and Action (Notre Dame: University of Notre Dame Press, 1979), 24.

${ }^{82}$ Aquinas, STh I, q. 3, a. 2, co.; I, q. 4, a. 2, co.; I, q. 11, a. 4, co.; I, q. 12, a. 1, co.; I, q. 14, a. 2, co.; and Albert, STh I, tr. 3, q. 13, cap. 6, ad 3 (t. 34/1, p. 50 11. 15-21); I, tr. 4, q. 19, cap. 1, passim (t. 34/1, pp. 91-92); I, tr. 4, q. 20, cap. 2 , obj. 4 (t. 34/1, p. 100 11. 71-87).

${ }^{83}$ See Aquinas, STh I, q. 2, a. 1, co., who explains that because God is His own to-be or existence, the proposition 'God exists' is self-evident in itself, though it is not self-evident to us on account of the fact that we do not know God's essence (quid est). See also Albert, STh I, tr. 4, q. 19, cap. 1, sol., who says of God: "But that properly exists in which that which is (id quod est) and to-be (esse) are the same" (t. 34/1, p. 92 11. 52-53).
} 
Already in our brief consideration of Aquinas and Albert on Job, we have come a long way from the standard modern approach sketched above and its assumptions concerning God's existence and operations. But let us continue further still.

\section{Evil, the Existence of God, and Providence}

'The problem of evil', as formulated by modern thinkers, is a particular postEnlightenment, philosophical conundrum. Whereas modern readers of Job often understand the book as, in Eleonore Stump's words, "the paradigmatic presentation of the problem of evil", no ancient or medieval Christian writer of whom I am aware read Job as treating the question of whether or how evil can be reconciled with God's existence. ${ }^{84}$ Although Aquinas' Expositio super Iob can be read as speaking to certain aspects of what moderns call 'the problem of evil', several scholars have noted that Aquinas himself is not here concerned with this problem. ${ }^{85}$ Brian Davies extends this claim to the entire Thomistic corpus:

Aquinas has nothing to say on this topic.... [H]e never offers a stand-alone discussion of what contemporary philosophers have come to call the problem of evil. He has no book or essay on it. He offers no full-length treatment starting along the lines 'God is X, Y, Z, etc.; yet evil exists; so how can we reconcile evil with God's existence?' In this sense, what now passes as the problem of evil goes unmentioned in Aquinas's writings. ${ }^{86}$

Though Aquinas nowhere provides a "full-length treatment" of the contemporary problem of evil, he is certainly aware of the basic line of argument, which he proposes as an objection to divine existence in STh I, q. 2, a. 3. If God, whose name signifies "a certain infinite goodness", existed, then no evil would be found in the world, since if one of two contraries is infinite, the other would be completely destroyed. ${ }^{87}$ Aquinas responds by maintaining that it pertains to God's infinite goodness to allow evil and to draw good out of it..$^{88}$

As we have seen, the fundamental problem that evil raises for Aquinas and Albert is not that of God's existence, but rather that of God's providence concerning human affairs. The existence of evil in the world never suggests to either theologian that God may not exist. In fact, just the opposite is true: both Aquinas and Albert take the reality of evil as evidence for divine existence. In Summa contra Gentiles Book III ch. 71, for instance, Aquinas counters those who deny the existence of God on account of

\footnotetext{
${ }^{84}$ Stump, Aquinas, 455; Kenneth B. Steinhauser, 'Job in Patristic Commentaries and Theological Works', in: Harkins, Canty, Companion to Job, 34-70; Harkins, Canty, Companion to Job, passim. See also Harkins, Thomas Aquinas, 107-109, on which the following discussion draws.

${ }^{85}$ See Harkins, 'Christ and the Eternal Extent', 161-62 and nn. 1-2.

${ }^{86}$ B. Davies, Thomas Aquinas on God and Evil (Oxford: Oxford University Press, 2011), 6.

${ }^{87}$ Aquinas, STh I, q. 2, a. 3, obj. 1.

${ }^{88}$ Aquinas, STh I, q. 2, a. 3, ad 1.
} 
the evil they observe in the world by maintaining that the reality of evil is not incompatible with either divine existence or divine providence. Remarking that Boethius, in Book I of Consolation of Philosophy, introduces a certain philosopher who asks, “If God exists, whence comes evil?," Aquinas observes: “On the contrary, however, he ought to have argued, 'If evil exists, God exists.' For evil would not exist if the order of good were removed, the privation of which is evil. But this order would not exist if God did not exist." ${ }^{89}$ Significantly, Aquinas here turns the standard problem-of-evil argument on its head: the reality of evil in the world presupposes a good order, which, in turn, presupposes God.

Whereas evil in the world never causes Aquinas and Albert to question divine existence, it does lead them to wonder how precisely God's providence operates. It seems that all things are not subject to divine providence, Aquinas notes, because a wise and omnipotent provider like God would, it appears, exclude all evil and defect from those in His care. ${ }^{90}$ Aquinas responds by distinguishing between God, as the universal provider, and any particular provider. Whereas a particular provider excludes defects from what she cares for as far as she can (think of a tomato farmer, for example, who makes every effort to produce healthy and delicious fruit), the universal provider, namely God, who takes care of "all being" (totius entis), permits certain defects in some things "lest the perfect good of the universe be hindered". ${ }^{91}$ For Aquinas, the good of the whole necessitates that there be inequality among things, some incorruptible and others corruptible, so that every grade of goodness might be realized. ${ }^{92}$ Thus, the perfect "order of the universe requires" (requirit) creatures that can be and sometimes are corrupted..$^{93}$ Aquinas explains: "If every evil were prevented, many good things would be absent from the universe. For no lion would live if there were no killing of animals, and there would be no patience of martyrs if there were no persecution by tyrants." 94

Similarly, Albert teaches that evils, although not directly caused by God, are certainly subject to divine providence. This is so, according to Albert, because all evils-whether evils of punishment or of fault-are "orderable" (ordinabilia), and indeed ordered, to a particular end. And providence signifies "the form of the order of all things to be conducted toward becoming, toward being (esse), toward conservation, and toward the things through which something is led to its proper end". ${ }^{95}$ Furthermore, because he understands God as altogether simple, Albert identifies God's providence with God Himself: "It must be said that God is the Highest

\footnotetext{
${ }^{89}$ ScG III, c. 71.

${ }^{90}$ Aquinas, STh I, q. 22, a. 2, obj. 2.

${ }^{91}$ Aquinas, STh I, q. 22, a. 2 ad 2.

92 Aquinas, STh I, q. 48, a. 2, co.

${ }^{93}$ Aquinas, STh I, q. 49, a. 2, co.; I, q. 48, a. 2 co., emphasis mine.

${ }^{94}$ Aquinas, STh I, q. 22, a. 2, ad 2.

${ }^{95}$ Albert, STh I, tr. 17, q. 67, m. 3, ad quaest. 4, ad 1: "Providentia autem per modum significandi designat ut formam ordinis omnium agendorum ad fieri, ad esse, ad conservationem, et ad ea per quae res ad debitum deducitur finem" (Opera Omnia, ed. A. Borgnet, vol. 31 [Paris: L. Vivès, 1894], p. 685b).
} 
Good, and God is His providence; and so the Highest Good is providence." 96 Thus, precisely in their being ordinabilia, evils point to God's providence, which is God, the Highest Good. Just as for Aquinas, then, so too for Albert, evil serves as evidence for the good order of things and therefore for the existence of God, who governs all things providentially. But because God's providential governing of human affairs may not always be obvious to us, both Aquinas and Albert understand this profound theological truth to have been revealed to and through Job.

\section{Conclusion}

In his 1977 Aquinas Lecture entitled "The Problem of Evil”, the philosopher Errol E. Harris declared:

Since biblical times the experience of evil has presented theists and theologians with what seems an insuperable obstacle to belief in the existence of a benevolent and all-powerful God. Unmerited misfortune and suffering, catastrophic disasters, and human malevolence have always seemed irreconcilable with an omnipotent creator of supreme justice and mercy. With this mystery Job and his admonitors wrestled. ${ }^{97}$

This is simply incorrect, as our foregoing analysis shows. Although evil may indeed present many modern people with "an insuperable obstacle" to belief in the existence of God, nowhere do either Job and his interlocutors, on the one hand, or Thomas Aquinas and Albert the Great, as commentators on Job, on the other, suggest that suffering is "irreconcilable" with an omnipotent and providential creator. Whereas Harris himself-like other modern philosophers such as J. L. Mackie, William Rowe, and J. L. Schellenberg-may have wrestled with the "mystery" of divine existence in the face of evil, the problem that stands at the heart of "the problem of evil' today was not the problem of either Job and his friends or Aquinas and Albert. The modern myopic view that the existence of evil represents a genuine threat to the existence of God should not be anachronistically retrojected into the past, blinding us to alternative perspectives on evil, God, and divine providence.

We have aimed to make clear just how differently Aquinas and Albert approach the reality of evil and suffering than do certain modern problem-of-evil philosophers. The perspective of our medieval Dominicans is not that of 'common theism', which treats both God and evil abstractly, detached from any particular religious narrative or theological context. ${ }^{98}$ Rather, as Catholic theologians, Aquinas

\footnotetext{
${ }^{96}$ Albert, STh I, tr. 17, q. 67, m. 3, ad quaest. 4, ad 1: “[D]icendum quod Deus est summum bonum, et Deus est sua providentia; et sic summum bonum est providentia" (Opera Omnia, ed. A. Borgnet, vol. 31, p. 685b). ${ }^{97}$ E.E. Harris, The Problem of Evil, The Aquinas Lecture 1977 (Milwaukee: Marquette University Publications, 1977), 1-2, emphasis mine.

${ }^{98}$ See K. Kilby, 'Evil and the Limits of Theology', in: New Blackfriars 84 (2003): 13-29, esp. 14.
} 
and Albert understand evil from within a theological tradition at the heart of which stands redemption through the suffering, death, and resurrection of Christ. ${ }^{99}$ With salvation through Christ as the paradigmatic example, Aquinas and Albert believe that all natural evil, including human suffering, comes ultimately from God and is ordered toward the good. The final good toward which the suffering of the saints, such as Job, is ordered is eternal life. On the reading of our Dominicans, Job's words in 19,25-27-For I know that my Redeemer lives, and on the last day I will rise from the earth, etc. - bespeak his hope in salvation through Christ, bodily resurrection, and beatific vision.

This interpretation of Job 19,25-27 illustrates the diametrical opposition, in fact, between the perspective of our medieval Dominican theologians and that of modern problem-of-evil philosophers such as Mackie and Rowe. In 1979 William Rowe took evil as evidence for the nonexistence of God, indeed as a straightforward "argument for atheism". Some seven centuries earlier, Aquinas was aware of thinkers who, like Rowe, denied divine existence on account of the evil they observed in the world. Whereas, for example, the philosopher mentioned by Boethius in Book I of Consolation of Philosophy asks, "If God exists, whence comes evil?", Aquinas claims that he ought to have argued the opposite, namely "If evil exists, God exists". ${ }^{100}$ Strikingly, Aquinas turns the basic problem-of-evil argument upside down: evil presupposes and is parasitic on a good order among creatures, and this good order presupposes a good God who creates and governs providentially. Albert too recognizes that evil presupposes God precisely because all evils are "orderable" (ordinabilia) to an end, the form of which order is God's providence, which, in turn, is - by virtue of divine simplicity-God Himself, the Highest Good.

Aquinas and Albert take 'God' to be the answer to the question 'Why is there anything rather than nothing?' The biblical account of Job is about many things rather than no things: it is about Job, his wife, his children, his servants, his sheep, camels, oxen, and donkeys. It narrates Job's righteousness and prosperity followed by the theft and destruction of his livestock, the slaughter of his servants, the death of his children, and his great suffering that followed from these losses. For Aquinas and Albert, all of these created things and all of the evils that befell them can ultimately be accounted for only by having recourse to God. As controversial as it may sound to modern ears, then, our medieval Dominicans understand evil as constituting compelling evidence that a good and providential God does exist. And because some people may have difficulty arriving at this truth naturally, God Himself has revealed it, according to Aquinas and Albert, in and through the book of Job.

${ }^{99}$ Harkins, Thomas Aquinas, 109-110.

100 ScG III, c. 71. 